\title{
Comparison of dye-based proteinuria estimation methods with immunoturbidimetric microalbuminuria estimation, in screening for diabetic nephropathy
}

\author{
Lalithambigai Arumugasamy
}

Assistant Professor, Dept. of Biochemistry, GMERS Medical College, Gotri, Vadodara, Gujarat, India

*Corresponding Author:

Email: drlalitha1981@gmail.com

Received: $13^{\text {th }}$ March, 2018

Accepted: $14^{\text {th }}$ April, 2018

\begin{abstract}
We compared the performance of Coomassie Brilliant Blue (CBB) and Ponceau S dyes based proteinuria estimation methods with immunoturbidimetry microalbumin estimation to develop new cut-offs for proteinuria, which would help us detect diabetic nephropathy patients with better sensitivity using the above mentioned dye based methods. These proteinuria testing methods are easy to adapt in smaller laboratories typically associated with peripheral government health centers.

Urine sample was collected from 158 diabetic individuals and tested simultaneously for Urine Albumin Creatinine ratio (UACR) using immunoturbidimetry and Urine Protein Creatinine Ratio (UPCR) using Ponceau S method and CBB method. The Ponceau $\mathrm{S}$ method gives good correlation with immunoturbidimetry, for screening of diabetic nephropathy, at UPCR cut-off of 50mg/g creatinine. The CBB method gives higher false positives. The overall agreement of Ponceau S and CBB with immunotubidimetry is maximum at cut off $50 \mathrm{mg} / \mathrm{g}$, i.e. $91 \%$ and $84 \%$ respectively.

In conclusion, proteinuria estimation with Ponceau S method with UPCR $>50 \mathrm{mg} / \mathrm{g}$ creatinine, may be used for routine screening of diabetic patients to diagnose microalbuminuria.
\end{abstract}

Keywords: Diabetic nephropathy screening, Proteinuria, Microalbuminuria, Ponceau S.

\section{Introduction}

Diabetic nephropathy is one of the leading causes of end stage renal disease (ESRD) and subsequent requirement for dialysis. ${ }^{7}$ Microalbuminuria is the earliest clinically detectable stage of diabetic nephropathy and at this stage, effective treatment with ACE inhibitors and good glycemic control can halt or even reverse the progression of microalbuminuria. ${ }^{4}$

The American Diabetes Association recommends use of microalbuminuria testing as a tool for early detection of diabetic nephropathy. ${ }^{3}$ Microalbuminuria is defined as excretion of urine albumin in the range of $30-300 \mathrm{mg} / \mathrm{g}$ creatinine. Microalbuminuria testing is done by immunoturbidimetry, which is expensive and is available only in Tertiary Care hospitals.

With a significant proportion of our population residing in rural areas and dependent on the government health care system, we require inexpensive methods to screen for diabetic nephropathy. Therefore it is the objective of this study to evaluate other methods for detection of proteinuria which would be sensitive enough to detect microalbuminuria and would be cheaper than the present immunoturbidimetric assay. A variety of methods have been described for sensitive diagnosis of proteinuria. ${ }^{6,1}$ L.A. McElderry et al compared six methods of urine protein estimation and concluded that Pesce \& Strande Ponceau S method and the Coomassie brilliant blue dye binding methods are more advantageous over the other methods. ${ }^{2}$ Hence it was decided to evaluate the performance of these two methods in the detection of microalbuminuria in diabetic individuals.

Further the present reference limit used for diagnosis of proteinuria is a protein: creatinine ratio of $>0.2$ i.e. $200 \mathrm{mg} / \mathrm{g}$ creatinine or $>150 \mathrm{mg} / \mathrm{dl}$ in a $24 \mathrm{hr}$ urine sample. ${ }^{5}$ In microalbuminuria, there is increased excretion of albumin alone in the initial stages and since albumin is the major urine protein excreted in these cases, using the above reference limit (i.e. $>30 \mathrm{mg} / \mathrm{g}$ creatinine) may not be sensitive enough for diagnosis of microalbuminuria. Therefore the results of immunoturbidimetry were compared with those obtained with the CBB dye method and the Ponceau S method to arrive at a new cut off or reference limit for interpretation of the Urine Protein Creatinine Ratio (UPCR) values obtained with these methods.

\section{Aim}

1. To find a cheap alternative method for screening diabetes patients to detect incipient diabetic nephropathy.

\section{Objectives}

1. Assessment of sensitivity of CBB dye based method and Ponceau $\mathrm{S}$ dye based method in detection of microalbuminuria associated with incipient diabetic nephropathy.

2. Establishing of a diagnostic cutoff level for proteinuria detected by CBB \& Ponceau S dye based methods, to achieve good correlation with diagnosis achieved with immunoturbibimetry. 


\section{Materials and Methods}

Diabetic individuals attending the OPD at Department of Diabetology, GGH, were enrolled into the study. Random urine samples were collected from 158 patients. Their albuminuria status was ascertained by immunoturbidimetric method. The protein excretion was also estimated using both Ponceau S and the CBB method.

The cases were selected based on the following criteria:

\section{Inclusion Criteria:}

1. Patients with DM of duration.

\section{Exclusion Criteria:}

1. Presence of UTI.

2. Presence of other complicating conditions such as infections, diabetic ketoacidosis, coronary artery disease, etc.

Random Mid-stream urine sample was collected for the UACR and UPCR estimations. Urine albumin was estimated as $\mathrm{mg} / \mathrm{dl}$ by Quantitative Immunoturbidimetric Method, using kit manufactured by Erba diagnostics. Urine creatinine was estimated as $\mathrm{g} / \mathrm{dl}$ by alkaline picrate based kit. Urine was diluted 1:25 before analysis. Urine albumin creatinine ratio was subsequently calculated.

$$
\operatorname{UACR}\left(\frac{m g}{g}\right)=\frac{\text { Urine albumin }\left(\frac{m g}{d l}\right)}{\text { Urine Creatinine }\left(\frac{g}{d l}\right)}
$$

Urine Protein Creatinine Ratio (UPCR) were also estimated simultaneously as described below.

Estimation of UPCR using Pesce \& Strande Ponceau S method.

Ponceau S stock solution was prepared by dissolving $40 \mathrm{~g}$ of Ponceau $\mathrm{S}$ dye in 1lt of distilled water.This was then diluted by mixing $20 \mathrm{ml}$ of Ponceau $\mathrm{S}$ stock solution to 1lt with Trichloro Aceticacid solution $(300 \mathrm{~g} / \mathrm{l})$. This is further diluted by making 100 $\mathrm{ml}$ of above reagent to $1 \mathrm{lt}$ with distilled water, to make the working reagent.

For preparing the calibration curve a pooled serum sample was taken, its concentration of total protein estimated, then dilution was done to make standards of concentration 2, 4, 6, 8, 10mg/dl.

To $1000 \mu$ of each standard, $100 \mu$ l of working reagent was added and mixed well. Then centrifugation was carried out for $10 \mathrm{~min}$ at $3500 \mathrm{rpm}$. The supernatant was removed. The precipitate was dissolved in $1 \mathrm{ml}$ $\mathrm{NaOH}(8 \mathrm{~g} / \mathrm{l})$ and the absorbance of the violet colour produced was measured at $546 \mathrm{~nm}$. The absorbance of the standards were plotted against the respective concentrations to get the calibration curve.

The samples were centrifuged before analysis for $15 \mathrm{~min}$ at $2500 \mathrm{rpm}$. Then the samples were subjected to same procedure as the standard, the absorbance reading was taken and the concentration estimated using the calibration curve.

Urine protein creatinine ratio was calculated by the following equation:

$$
\begin{aligned}
& \operatorname{UPCR}\left(\frac{m g}{g}\right) \\
& =\frac{\text { Urine Protein Concentration }\left(\frac{m g}{d l}\right)}{\text { Urine Creatinine Concentration }\left(\frac{g}{d l}\right)}
\end{aligned}
$$

Estimation of UPCR using CBB dye method (Bradford protein assay procedure).

CBB stock solution was prepared by dissolving $100 \mathrm{mg}$ of CBB G250 dye in $50 \mathrm{ml}$ methanol. This is then added to $100 \mathrm{ml}$ of $85 \%$ Orthophosphoric acid and made upto $200 \mathrm{ml}$ with distilled water. This stock solution should be stored in a dark bottle at $4^{\circ} \mathrm{C}$. The working reagent is prepared by diluting 1 volume of the stock solution in 4 volumes of distilled water.

For preparation of the calibration curve standards are prepared as previously described. To $600 \mu \mathrm{l}$ of standard $400 \mu$ l of working reagent is added. The test tube is covered with a parafilm and mixed well by inversion. The absorbance is measured at $595 \mathrm{~nm}$ and plotted against the concentration to get a calibration curve.

The samples were centrifuged before analysis for $15 \mathrm{~min}$ at $2500 \mathrm{rpm}$. Then the samples were subjected to same procedure as the standard, the absorbance reading was taken and the concentration estimated using the calibration curve.

The UPCR is calculated again, using the equation described previously.

\section{Statistical Analysis}

Following classification of the data based on UACR as $<30 \mathrm{mg} / \mathrm{g}$ creatinine and 30 to $300 \mathrm{mg} / \mathrm{g}$ creatinine, the results were tabulated.

To evaluate the performance of the two protein estimation methods, calculations of sensitivity and specificity were performed at the UPCR cut offs of 30 , $40,50,60 \mathrm{mg} / \mathrm{g}$ creatinine. Further overall agreement and kappa values were calculated. Spearman's correlation coefficient test was used to estimate the strength of association of the UACR values obtained with immunoturbidimetry and UPCR values obtained with Ponceau S and CBB dye methods. Regression analysis was performed to derive a regression equation which can compute UACR ratio from UPCR values obtained with the above two methods.

\section{Results and Discussion}

By immunoturbidimetric method 57 of the 158 diabetics enrolled as cases were found to be normoalbuminuric (UACR < 30mg/g creatinine) and 101 had UACR $>30 \mathrm{mg} / \mathrm{g}$ creatinine.

Table 1 and Table 2 displays the sensitivity and the specificity of the two dye based methods at various cut offs. The percentage overall agreement (with respect to microalbuminuria detected with immunoturbidimetry) and kappa values are also shown.

Table 3 and Table 4 shows the correlation coefficient and regression equation of the UPCR values 
obtained with the 2 methods with respect to the UACR obtained with immunoturbidimetry.

UPCR estimated with the Ponceau S method is more consistent with the results obtained with immunoturbidimetry, as seen from a correlation coefficient of 0.87 at $p<0.1$. In comparison the correlation coefficient of the CBB method is only 0.75 at $\mathrm{p}<0.01$.

The Ponceau $\mathrm{S}$ method gives maximum sensitivity of detection at $<40 \mathrm{mg} / \mathrm{g}$ creatinine but at these levels the specificity is only $67 \%$. The specificity is maximum at $60 \mathrm{mg} / \mathrm{g}$ but the sensitivity is decreased to $88 \%$. The cut off of $50 \mathrm{mg} / \mathrm{g}$ seems ideal as it gives a sensitivity of $96 \%$ with a specificity of $82 \%$. The decreased in specificity i.e. the false positive cases are due to increased excretion of proteins other than albumin. So stringent control of sample collection and prevention of testing in conditions such as UTI, fever etc., which cause proteinuria, would improve specificity.
The CBB method gives higher amount of false positives. The best sensitivity achievable is $98 \%$ at cut off $<30 \mathrm{mg} / \mathrm{g}$ but this has very poor specificity $39 \%$. Maximum specificity is $84 \%$ with cut off $<50$ $\&<60 \mathrm{mg} / \mathrm{g}$ of these only the former gives a reasonable sensitivity of $83 \%$.

The overall agreement of Ponceau $\mathrm{S}$ and $\mathrm{CBB}$ is maximum at cut off $50 \mathrm{mg} / \mathrm{g}$, i.e. $91 \%$ and $84 \%$ respectively. The kappa values are also maximum at the same cut offs.

The regression equations shown can be used to calculate UACR corresponding to the UPCR values obtained with the 2 methods.

The cost analysis (Table 4) is shows the cost of performing Ponceau $\mathrm{S}$ method is apprx. 10p/test and that of $\mathrm{CBB}$ method is 5p/test. The cost of immunoturbidimetry is Rs 50-90/test.

Table 1. Evaluation of sensitivity and specificity of UPCR estimation by Ponceau S method in comparison with UACR by Immunoturbidimetric method, in detection of microalbuminuria

\begin{tabular}{|c|c|c|c|c|}
\hline Cut off & Sensitivity & Specificity & Overall agreement & Kappa value \\
\hline $30 \mathrm{mg} / \mathrm{g}$ & 100 & 63 & 86 & 0.69 \\
\hline $40 \mathrm{mg} / \mathrm{g}$ & 100 & 67 & 87 & 0.71 \\
\hline $50 \mathrm{mg} / \mathrm{g}$ & 96 & 82 & 91 & 0.81 \\
\hline $60 \mathrm{mg} / \mathrm{g}$ & 88 & 86 & 87 & 0.73 \\
\hline
\end{tabular}

Table 2: Evaluation of sensitivity and specificity of UPCR estimation by CBB dye based method in comparison with UACR by immunoturbidimetric method, in detection of microalbuminuria

\begin{tabular}{|c|c|c|c|c|}
\hline Cut off & Sensitivity & Specificity & Overall agreement & Kappa value \\
\hline $30 \mathrm{mg} / \mathrm{g}$ & 98 & 39 & 77 & 0.47 \\
\hline $40 \mathrm{mg} / \mathrm{g}$ & 87 & 58 & 77 & 0.50 \\
\hline $50 \mathrm{mg} / \mathrm{g}$ & 83 & 84 & 84 & 0.67 \\
\hline $60 \mathrm{mg} / \mathrm{g}$ & 69 & 84 & 74 & 0.49 \\
\hline
\end{tabular}

Table 3: Comparison of correlation coefficient

\begin{tabular}{|l|c|c|}
\hline \multicolumn{1}{|c|}{ Method } & Spearman's rank correlation coefficient & p value \\
\hline Ponceau S method & 0.87 & $4.25 \mathrm{E}-46$ \\
\hline CBB dye method & 0.75 & $6.07 \mathrm{E}-26$ \\
\hline
\end{tabular}

Table 4: Comparison of regression equations

\begin{tabular}{|l|c|c|c|}
\hline \multicolumn{1}{|c|}{ Method } & Regression equation & r-squared & p value \\
\hline Ponceau S method & $\mathrm{Y}=0.897 \mathrm{X}-9.746$ & 0.553 & $3.78 \mathrm{E}-27$ \\
\hline CBB dye method & $\mathrm{Y}=1.32 \mathrm{X}-24.99$ & 0.358 & $1.51 \mathrm{E}-15$ \\
\hline
\end{tabular}

Table 5: Cost Analysis

\begin{tabular}{|c|c|}
\hline Method for screening & Cost per test \\
\hline 1. Immunoturbidimetric method & Rs $50-90$ \\
\hline $\begin{array}{l}\text { 2. Pesce \& Strande Ponceau S method } \\
\text { Reagents } \\
\text { i. Ponceau S dye Rs } 400 / 25 \mathrm{~g} \\
\text { ii. Trichloroaceticacid Rs } 130 / 100 \mathrm{~g} \\
\text { iii. Sodium hydroxide Rs } 175 / 500 \mathrm{~g} \\
\text { considering all dilutions } 80 \mathrm{mg} \text { of Ponceau S, } 30 \mathrm{~g} \text { TCA and } 11 \mathrm{t} \text { of } 8 \mathrm{~g} / 1 \mathrm{NaOH} \text { is required to } \\
\text { prepare } 1 \mathrm{lt} \text { working reagent which can be used to perform } 10000 \text { tests. }\end{array}$ & Approx $10 \mathrm{p}$ \\
\hline $\begin{array}{l}\text { 3.CBB dye binding method } \\
\text { Reagents } \\
\text { i. CBB G250 dye Rs } 530 / 5 \mathrm{~g} \\
\text { ii. Methanol Rs } 350 / 500 \mathrm{ml} \\
\text { iii. Phosphoric acid Rs } 425 / 500 \mathrm{ml} \\
\text { considering all dilutions } 100 \mathrm{mg} \mathrm{CBB}, 50 \mathrm{ml} \text { methanol and } 100 \mathrm{ml} \text { phosphoric acid is required } \\
\text { to prepare } 11 \mathrm{t} \text { working reagent which can be used to perform } 2500 \text { tests. }\end{array}$ & Approx $5 \mathrm{p}$ \\
\hline
\end{tabular}

International Journal of Clinical Biochemistry and Research, July-September, 2018;5(3):375-378 


\section{Conclusion}

Taking the results of the study into consideration, along with the low cost of performing Ponceau $S$ method, it is concluded that UPCR $>50 \mathrm{mg} / \mathrm{g}$ creatinine, using the Ponceau $\mathrm{S}$ method may be used for routine screening of diabetic patients to diagnose microalbuminuria.

\section{References}

1. Bradford MM. A rapid and sensitive method for quantitation of microgram quantities of protein urilizing the principle of protein dye binding. Anal Biochem. 72, 248-254.

2. McElderry LA, Tarbit IF and Cassells-Smith AJ. Six methods of urine protein compared. Clin Chem. 1982 Feb;28(2):356-360.

3. Microvascular Complications and Foot Care Diabetes Care. 2017;40(Suppl. 1):S88-S98 | DOI:10.2337/dc17S013.
4. Molitch ME, DeFronzo RA, Franz MJ, Keane WF, Mogensen CE, Parving HH et al. Diabetic nephropathy. Diabetes Care. 2002 Jan 1;25(Suppl. 1).

5. Rao LV, Pechet L, Jenkins A et al. Chapter 2: Laboratory tests. Wallach's Interpretation of Diagnostic Laboratory Tests. Ninth edition. Pg. 310.

6. Savory J, Pu PH and Sunderman FW Jr. A biuret method for determination of protein in normal urine. Clin chem.14, 1160-1171.

7. Tuttle KR, Bakris GL, Bilous RW, et al. Diabetic kidney disease: a report from an ADA Consensus Conference. Diabetes Care. 2014;37:2864-2883.

How to cite this article: Arumugasamy L. Comparison of dye-based proteinuria estimation methods with immunoturbidimetric microalbuminuria estimation, in screening for diabetic nephropathy. Int. J Clin Biochem Res. 2018;5(3):375-378. 